\title{
The Principle of Inferential Justification, Scepticism, and Causal Beliefs
}

\section{Josep E. Corbí} like:

There is an argumentative route that begins with a platitude

The Principle of Inferential Justification (PIJ): "To be justified in believing one proposition $P$ on the basis of another proposition $E$, one must be (1) justified in believing $E$, (2) justified in believing that $E$ makes probable $P$ ". ${ }^{1}$

and ends up by challenging our capacity to justifiedly believing propositions concerning physical objects and past events. This is, at least, what Richard Fumerton claims, but, like Christopher Hookway, ${ }^{2}$ I doubt that there is such a route.

The plausibility of PIJ in ordinary contexts relies, according to Hookway, on a number of assumptions like, for instance, the need to distinguish between salient information and background view of things. The problem is that Fumerton's sceptical route requires the application of PIJ not only to particular beliefs but to broad 
epistemic classes of beliefs and, as Hookway tries to emphasize, this strategy is ultimately inconsistent with the need to maintain the aforementioned distinction and, in general, with the assumptions that rendered PIJ plausible in the first place. This worry is not, on the other hand, unconnected with the conviction that, contrary to what Fumerton claims, the notion of justification is inextricably associated with our needs to make normative judgements. As Hookway puts it, "... None who was not sensitive to our needs to make normative judgments could understand or share our concepts of rational belief or cruelty; they would not be able tolsee how the terms should be applied to wholly novel kinds of cases for they would lack the sense of what is "evaluatively similar' which is required for doing this." 3

In the coming pages, I seek to show how Hookway's challenge may find additional motivation in a reflection on the content of a certain kind of belief, namely: beliefs about particular causal processes. To this purpose, I shall firstly point out two assumptions on which Fumerton's sceptical route relies. Secondly, I will explore how these two assumptions are linked to reductionist accounts of causation and, consequently, to a certain view about the content of our causal beliefs. More specifically, I will argue that Fumerton's line of argument does not follow from a rather uncontentious understanding of PIJ, but on a certain interpretation of it that presupposes the availability of a reductionist account of causation. This upshot will certainly diminish the appeal of Fumerton's route insofar as its plausibility will now depend on a rather substantial and controversial metaphysical contention. Relatedly, it will become clear that, if the project of the causal reductionist would after all fail, then one should accept that the conditions under which a belief about a particular causal process is justified cannot be enumerated independently of the normative constraints that are proper to a certain causal inquiry. And this will surely come to reinforce Hookway's critical intuitions.

\section{Two assumptions in Fumerton's sceptical route}

For the sake of simplicity, I will focus on Fumerton's presentation of the structure of sceptical arguments about "our access to the past through memory", ${ }^{4}$ which he envisages as fundamental, although much of what I will say about this case also applies to sceptical arguments concerning our beliefs about physical objects. 
Fumerton insists that, according to PIJ, one could only justifiedly believe $\mathrm{P}$ on the basis of memory experiences if one could justifiedly believe that memory experiences are reliable indicators of past events. The problem is that there is no way in which one could justifiedly have such a belief. Inductive inference would be useless at this juncture because one could not justifiedly belief the premise of that inference. As Fumerton puts it, "an inductive justification for the reliability of memory would proceed from a premise describing correlations between past memory experiences and the events we took them to correctly represent" ${ }^{5}$. It follows from these remarks, however, that

(A) There are certain facts (i.e., facts concerning a correlation between past events and memory experiences) with regard to which we cannot have justified beliefs under any circumstances. And, nevertheless, they are such that, if we could have rational beliefs about them, then we could determine whether we can have justified beliefs about the past on the basis of memory experiences.

This is the first assumption I intended to highlight; the second has been appropriately stressed by Hookway in his paper. As he points out, cases where PIJ sounds plausible are concerned with the justification of a particular belief where we rely on our ability to pick out salient information against a background view of things, and not with a broad class of belief. Fumerton, however, takes PIJ out of these ordinary contexts, and applies it to the evaluation of broad epistemic classes of beliefs. He assumes that

(B) the conditions under which beliefs of a certain class may be justified can be specified independently of the fact that, against a certain background view, a bit of information may count as evidence in favour of a particular belief of that class.

This assumption sounds quite reasonable if one judges that part of what clause (1) in PIJ demands is that we should be justified in holding the background view against which the epistemic relevance of a bit of information is to be assessed. And one might think that, according to PIJ, one could only rationally believe in a background view if one could justifiedly believe all the propositions that compose that background view. This amounts to assuming that the distinction between background view and salient information is ultimately irrelevant from the viewpoint of justifi- 
cation or, in other words, that the conditions under which a belief is justified are not relative to a certain background view that is taken for granted. ${ }^{6}$ In terms due to. Hookway, we can say that (B) characterises a substantial notion of justification, which opposes to a contextualist proposal according to which questions about justification "arise within specific contexts, influenced by a body of background certainties, shaped by the goals which govern our inquiries and so on." 7

Let us now see how assumptions (A) and (B) are connected to different accounts of causation. I will, in this respect, argue that àssumptions (A) and (B) would after all be unintelligible if the causal anti-reductionist were right and, therefore, that Fumerton's sceptical route relies on the success of causal reductionism. To reach this conclusion I will rely on a plausible claim, namely: that, if causal reductionist projects would ultimately fail, then the distinction between a cause and its background conditions will come up as metaphysically indispensable, as a distinction that will irreducibly intervene in the individuation of causes. ${ }^{8}$

\section{Causal anti-reductionism and Fumerton's assumptions}

To see how Fumerton's sceptical route depends on the success of causal reductionism, let us reflect about how the collapse of the latter may affect the assumptions on which Fumerton's argument relies. Suppose then that, as the causal anti-reductionist claims, the individuation of a cause is irreducibly relative to some background conditions, and consider my belief that

\section{(1) The bridge collapsed because this bolt snapped}

Under what conditions may I be justified in believing (1)? Let us assume that (1) is a belief of the class contemplated by PIJ, namely: a belief that one holds "on the basis of others or on the basis of some body of evidence." ${ }^{9} \mathrm{We}$ are then entitled to ask: what is the $\mathrm{E}$ on the basis of which (1) may be rationally endorsed? We may surely justify a particular causal belief like (1) against a certain background of causal beliefs. My point is, however, that, if the reductionist project is damned, then one cannot intelligibly ask for the sort of justification that Fumerton's sceptical route requires, that is, the kind of justification that a causal belief about 
a particular causal process would have in virtue of our justifiedly believing that a certain kind of correlation holds, namely: a correlation to which, as a matter of principle, we cannot have any epistemic access. For either that correlation involves particular causal facts or it does not. If it does not, the causal antireductionist will deny that any fact of such a kind might even count as a candidate for justifying a belief about a particular causal fact. For if there were any necessary correlation between noncausal facts, that notion of 'necessity' would have, ex hypothesi, nothing to do with the causal notion of 'necessary condition', that is, with the kind of necessary connection that would render that causal belief true. If, on the contrary, the correlation at stake does involve some particular causal facts, then it cannot be envisaged, in contrast with what Fumerton's route presupposes, as entirely independent of our epistemic ability to highlight a cause against certain background conditions, since, for a causal antireductionist, all particular causal facts are indispensably individuated in the light of that contraposition.

It is clear besides that, with regard to each particular causal process, there is a number of different ways in which the distinction between causes and background conditions may legitimately be drawn and, consequently, that there is no metaphysically privileged stance from which that distinction should be drawn. It is only relative to the interests and procedures that define a given causal inquiry that a certain way of drawing the distinction may appear as appropriate. It follows that, if the causal anti-reductionist is right, particular causal facts are in part metaphysically individuated by our ability to pick up causes against their respective background conditions in the context of a certain causal inquiry. And this should indeed be construed as a metaphysical claim, not merely as a statement about the meaning of 'particular causal facts'. ${ }^{10}$ We can then say that, insofar as Fumerton conceives the kind of fact to which assumption (A) appeals as causal, he cannot assume that such a fact can be individuated independently of the purposes of a certain causal inquiry and, in general, of our epistemic ability to pick out a cause against its causal background. For what the causal anti-reductionist denies is precisely that there might be particular causal facts whose individuation were constitutively independent of that epistemic ability. But, if Fumerton's causal facts are defined as epistemically inaccessible, how could they depend on our epistemic ability to draw the relevant distinction between the cause and its causal background? We can thus 
conclude that the intelligibility of assumption (A) depends on the success of the reductionist project with regard to causation.

This line of reasoning is also relevant to assumption (B). Our previous remarks serve to motivate not only the idea that the distinction between salient information and background view is constitutive of our beliefs about particular causal processes, but also the claim that that distinction is indispensable in the determination of the conditions under which an agent may be justified in holding any such belief. We have seen that, if the causal antireductionist is right about the way the content of certain causal beliefs is determined, then having those causal beliefs involves the ability to individuate causes within a certain causal background. It is proper, however, to any ability that its possession is not accidentally connected to its displays. Hence, having the epistemic ability to set apart the cause from its causal background, entails that the agent's causal beliefs do not bear a merely accidental relation to the causal facts. But what should count as an appropriate relation to the particular causal facts? Can it be determined regardless of the causal inquiry that contributes to fix the relevant particular causal facts, that is, independently of the procedures that are recognized as appropriate within that causal inquiry?

It is part of the anti-reductionist conclusion that particular causal facts are fixed relative to a certain epistemic perspective, to a certain relation of the epistemic agent to the world that is recognized as relevant in the context of a given investigation. A contextualist notion of justification would characterise that epistemic perspective (and, indeed, the appropriate relation to the causal facts) as dependent on the purposes of the causal inquiry. By contrast, a substantial notion of justification would attempt to characterise that epistemic perspective independently of any causal inquiry; in other words, this substantial notion would presuppose the possibility of presenting that perspective as a context-free relation $R$ between an agent $A$ and certain facts. Yet, if Fumerton would construe relation $R$ as depending on some particular causal facts, trivially the anti-reductionist would insist that its identification would inevitably be relative to the interests and procedures of a given a causal inquiry and, consequently, relation $\mathrm{R}$ could hardly serve the purposes of a substantial notion of justification. Suppose, on the contrary, that Fumerton would envisage $R$ as independent of any particular causal fact. In that case, if $R$ is to grasp the conditions under which agent $A$ would be justified 
in having a belief about a particular causal fact, then $\mathrm{R}$ should, among other things, determine whether $\mathrm{A}$ has the ability to draw the relevant distinction between the cause and its causal background. But this amounts to saying that there is an independent metaphysical relation that may account for that ability, whereby the ability at stake would come up as metaphysically irrelevant with regard to the individuation of particular causal processes. But this is precisely what the causal anti-reductionist denies. It follows that, if the anti-reductionist is right, then no substantial notion of justification is available with regard to a certain kind of belief, namely: beliefs about particular causal processes. This result surely clashes with assumption (B) and, consequently, calls into question the intelligibility of applying PIJ to that class of belief.

It is easy to see, however, that this line of reasoning may give rise to a more general challenge. Consider, in this respect, how the correlation between, say, past events and memory experiences, should be construed according to assumption (A). Either it relies on particular causal processes or it does not. In the former case, our previous line of argument trivially applies. In the latter case, Fumerton would have to present the correlation at stake as the outcome of an inductive inference on the basis of some noncausal sequences. Yet, it sounds reasonable to reply that if, as we are assuming, particular causal facts are metaphysically irreducible, then a legitimate inductive inference of that kind cannot be ultimately alien to the kind of metaphysical dependence that articulates such facts. And, consequently, we may affirm that, if any noncausal sequence may appropriately act as the basis of an inductive inference, that sequence could not be construed as totally independent of particular causal facts. It follows that the only way in which the anti-reductionist can interpret Fumerton's sceptical route about physical objects and the past, is such that the facts that are mentioned in assumption (A) involve particular causal processes. But we have seen that on this interpretation assumption (A) is unintelligible to the causal anti-reductionist.

\section{NOTES}

1. Fumerton (1995), p. 36.

2. Cf. Hookway (2000).

3. Hookway (1998), p. 911.

4. Fumerton (1995), p. 34 . 
5. Fumerton (1995), p. 35. Fumerton describes the structure of sceptical arguments about the past like this:

"The argument for strong skepticism with respect to the past also relies on clause 2 insisting that any justified conclusion about the past inferred from what we seem to remember must include justification for believing that memory experiences are a reliable indicator of past events. Again, when an inductive justification of such reliability is attempted, clause 1 of the principle invoked to challenge our ability to rationally believe the premise of the inductive argument, a premise that will describe past events and again require an inference based on memory." (p. 36)

It is easy to see that this strong scepticism about our access to the past based on memory experiences can hardly be conceived as local, that is, as being merely concerned with an isolated class of beliefs. For it seems clear that such beliefs are inevitably involved in the justification of any other belief that one might have. Cf. Fumerton (1995, p. 50).

6. Hookway (2000) describes Fumerton's stance on this issue as follows: "In assessing the proposition, we are concerned with every item of information that is in any way relevant to the rationality of our acceptance of it. The concern of all possible evidence rather than with salient evidence is linked to the focus upon broad epistemological qualification rather than with specific concrete classifications." (p. 348)

7. Hookway (2000, p. 359$)$.

8. For a detailed defence of this claim, cf. Corbí and Prades (2000), ch. 5 .

9. Hookway $(2000$, p. 345$)$. This is surely the most favourable option for Fumerton's purposes.

10. It is important to notice that my anti-sceptical argument does have the following shape:

"If we think of the world as containing particular causal processes, then we are able to identify particular causal processes."

In this respect, my argument certainly parallels the kind of anti-sceptical statement that Barry Stroud (1968) imputes to Peter F. Strawson, although the latter is concerned with the identification not of particular causal processes, but of particular objects. There is, however, a difference that I judge crucial. My rebuttal of the sceptical argument rests on a preliminary exploration of the conditions under which particular causal processes may be individuated. It is only after the conclusion has been reached that the distinction between the cause and its background conditions is metaphysically indispensable, that one can legitimately affirm that conditional statement.

\section{REFERENCES}

Corbí, J. E. and Prades, J. L. (2000), Minds, Causes, and Mechanisms. A Case Against Physicalism, Oxford, Blackwell Publishers. 
Fumerton, R. (1995), Metaepistemology and Skepticism, Boston, Rowman \& Littlefield Publishers.

Hookway, C. (1998), "Normative concepts and epistemological internalism", Philosophy and Phenomenological Research, vol. LVIII, No. 4, pp. 907-912.

Hookway, C. (2000), "Scepticism and the principle of inferential justification", this volume.

Stroud, B. (1968), "Transcendental Arguments", The Journal of Philosophy, vol. LXV, no. 9, pp. 241-56. 


\section{PHILOSOPHICAL ISSUES}

Co-editors:

Ernest Sosa

Enrique Villanueva

Brown University and Rutgers University Universidad Nacional Autónoma de México

Managing Editor:

Suzanne Bertrand Brown University

Editorial Advisory Board:

Ned Block

Paul Boghossian

Jerry Fodor

Richard Foley

James Higginbotham Jaegwon Kim

Brian Loar

Christopher Peacocke Sydney. Shoemaker

James Tomberlin
New York University

New York University

Rutgers University

Rutgers University

University of Southern California

Brown University

Rutgers University

University of Oxford

Cornell University

California State University, Northridge

Previously published volumes (which are available from Ridgeview Publishing Company, Box 686, Atascadero, CA 93423):

CONSCIOUSNESS, Volume I, 1991

RATIONALITY IN EPISTEMOLOGY, Volume II, 1992

SCIENCE AND KNOWLEDGE, Volume III, 1993

NATURALISM AND NORMATIVITY, Volume IV, 1993

TRUTH AND RATIONALITY, Volume V, 1994

CONTENT, Volume VI, 1995

PERCEPTION, Volume VII, 1996

TRUTH, Volume VIII, 1997

CONCEPTS, Volume IX, 1998

Forthcoming volumes (which will be available from Blackwell Publishers, 350 Main Street, Malden, MA 02148):

PHILOSOPHY OF LAW AND SOCIAL PHILOSOPHY, Volume XI, 2001

SOCIAL CONSTRUCTION, OBJECTIVITY, AND

REALISM, Volume XII, 2002 
Philosophical Issues, 10, 2000

\title{
SKEPTICISM
}

\author{
edited by
}

Ernest Sosa and Enrique Villanueva 


\title{
tabla de contenidos
}

\author{
publicación Nous \\ ISSN 0029-4624 electrónico 1468-0068 \\ editor Blackwell Publishing \\ año - volumen - número - parte 2000 - 34 - 1 - SUPPL \\ acceso tabla de contenido
}

gratuito con la versión impresa

ver los detalles de la publicación

número anterior número siguiente

artículos

Skepticism and Contextualism

Sosa, Ernest

páginas: 1

añadir al archivador

\section{Skepticism, Tracking, and Warrant}

Tomberlin, James $E$

páginas: 19

Qt añadir al archivador pedir el artículo

The Contextualist Evasion of Epistemology

Kornblith, Hilary

páginas: 24

औñadir al archivador

Sensitivity, Indiscernibility and Knowledge

Lehrer, Keith

páginas: 33

अ añadir al archivador $\$$ pedir el artículo

\section{Replies}

Sosa, Ernest

páginas: 38

3 añadir al archivador ${ }^{*}$ pedir el artículo

Contextualism and Externalism: Trading in One Form of Skepticism for Another

Fogelin, Robert J

páginas: 43

१añadir al archivador pedir el artículo

\section{Scrutinizing a Trade}

Rosenberg, Jay $F$

páginas: 58 
What Has Contextualism to Do with Skepticism?

Villanueva, Enrique

3 añadir al archivador $\%$ pedir el artículo

Contextualism and Levels of Scrutiny

Valdés-Villanueva, Luis $M$

páginas: 72

añadir al archivador

Is Contextualism Statable?

Williams, Michael J

páginas: 80

3. añadir al archivador

\section{Replies}

Fogelin, Robert $J$

páginas: 86

2 añadir al archivador pedir el artículo

\section{Contextualism and Skepticism}

Cohen, Stewart

páginas: 94

2. añadir al archivador ${ }^{*}$ pedir el artículo

Contextualism and the Real Nature of Academic Skepticism

Klein, Peter D

páginas: 108

añadir al archivador

\section{Reply to Cohen}

Hawthorne, John

páginas: 117

añadir al archivador pedir el artículo

\section{Scepticism, Contextualism and Closure}

Prades, Josep $L$

1. añadir al archivador

\section{Replies}

Cohen, Stewart

3 añadir al archivador $\$$ pedir el artículo 
अ añadir al archivador

On Wright's Diagnosis of McKinsey's Argument

Suárez, Alfonso Garcia

páginas: 164

1 añadir al archivador $\%$ pedir el artículo

\section{Transmission and Closure}

Hale, Bob

páginas: 172

3 añadir al archivador pedir el artículo

Warrant-Transmission, Defeaters and Disquotation

Sainsbury, R.M

páginas: 191

añadir al archivador pedir el articulo

\section{Replies}

Wright, Crispin

páginas: 201

3 añadir al archivador

\section{Vagueness and Partial Belief}

Schiffer, Stephen

páginas: 220

2. añadir al archivador pedir el artículo

\section{Vagueness and Indirect Discourse}

Garcia-Carpintero, Manuel

páginas: 258

\% añadir al archivador pedir el artículo

\section{Stephen Schiffer's Theory of Vagueness}

Horwich, Paul

páginas: 271

Q3 añadir al archivador $\$$ pedir el artículo

\section{Vagueness as a Psychological Notion}

Valdivia, Lourdes

páginas: 282

añadir al archivador pedir el artículo

\section{Partial Belief and Borderline Cases}

Marqueze, Jorge Rodríguez

páginas: 289

$$
\text { १ añadir al archivador } 1 \text { pedir el articulo }
$$

\section{Vagueness-Related Attitudes}

Barnett, David

páginas: 302 
3. añadir al archivador

Replies

Schiffer, Stephen

páginas: 321

Qn añadir al archivador pedir el artículo

Scepticism and the Principle of Inferential Justification

Hookway, Christopher

páginas: 344

añadir al archivador $\%$ pedir el artículo

Scepticism and Epistemic Kinds

Greco, John

páginas: 366

3 añadir al archivador pedir el artículo

The Principle of Inferential Justification, Scepticism, and Causal Beliefs Corbi, Josep E

páginas: 377

añadir al archivador pedir el artículo

Memory and Justification: Hookway and Fumerton on Scepticism

Moya, Carlos J - Grimaltos, Tobies

páginas: 386

3. añadir al archivador $\$$ pedir el artículo

Replies

Hookway, Christopher

páginas: 395

añadir al archivador ${ }^{\circ}$ pedir el artículo

\section{Contributors}

páginas: 400

Qñadir al archivador pedir el artículo

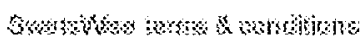

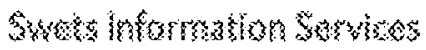

